\author{
Е.Г. Калитина ${ }^{1}$, Т.А. Михайлик ${ }^{2}$, П.Ю. Семкин ${ }^{2}$, \\ Ю.А. Барабанщиков ${ }^{2}$, С.А. Зорин ${ }^{1 *}$ \\ ${ }^{1}$ Дальневосточный геологический институт ДВО РАН, \\ 690022, г. Владивосток, просп. 100 лет Владивостоку, 159; \\ 2 Тихоокеанский океанологический институт им. В.И. Ильичева ДВО РАН, \\ 690041, г. Владивосток, ул. Балтийская, 43
}

\title{
ОСОБЕННОСТИ МИКРОБИОЛОГИЧЕСКОГО СОСТАВА ВОД РЕКИ РАЗДОЛЬНОЙ (ЮЖНОЕ ПРИМОРЬЕ)
}

\begin{abstract}
Произведена оценка численности и ее сезонной изменчивости для различных индикаторных групп микроорганизмов в поверхностных водах р. Раздольной. Результаты исследования показали, что они подвержены высокому комплексному органическому, техногенному и микробиологическому загрязнению. В поверхностных водах р. Раздольной были выявлены эколого-трофические группы микроорганизмов, которые принимали участие в очищении вод реки. Однако из-за постоянного притока сточных вод бактерии не успевали перерабатывать поступающее органическое вещество, что указывает на неспособность данной экосистемы к полному самоочищению. Согласно классификатору качества вод, воды р. Раздольной по микробиологическим показателям отнесены к грязным в летний сезон, к загрязненным в весенний и осенний периоды и к чистым в зимний сезон.

Ключевые слова: река Раздольная, эколого-трофические группы, колиформные бактерии, бактерии цикла серы, нитрификация, микробоценоз.
\end{abstract}

Kalitina E.G., Mikhailik T.A., Semkin P.Yu., Barabanshchikov Yu.A., Zorin S.A. Features of microbiological composition for water from the Razdolnaya River (southern Primorye) // Izv. TINRO. - 2015. - Vol. 180 - P. 187-197.

The Razdolnaya is one of the biggest rivers of southern Primorye flowing into the Japan Sea. Bacteria abundance in its water is evaluated using Koch method and ultimate dilution. Number of metal-resistant bacterial forms is determined on selective media prepared on the base of agar supplemented with metal salts at the concentrations inhibiting growth of the sensitive forms. Fecal contamination is assessed by counting of common coliform bacteria (CCB) and thermo-tolerant coliform bacteria (TCB) cultured on the selective medium Endo. High organic, technological and microbiological pollution of water at the Razdolnaya River surface is revealed, that is caused by its wasting by both organic and inorganic substances. The river water contains organotrophic and lithotrophic microorganisms which maintain geochemical cycles providing its self-purification, but they are not able to assimilate completely the whole volume of incoming

* Калитина Елена Геннадьевна, кандидат биологических наук, научный сотрудник, е-таil: microbiol@mail.ru; Михайлик Татьяна Александровна, младший научный сотрудник, е-таil: Tatyana_libra@mail.ru; Семкин Павел Юрьевич, младший научный сотрудник, e-mail: Pahno@, list.ru; Барабанщиков Юрий Александрович, аспирант, е-тail: biw90@таil.ru; Зорин Станислав Александрович, аспирант, e-mail: stive01@mail.ru.

Kalitina Elena G., Ph.D., researcher, email: microbiol@mail.ru; Mikhailik Tatiana A., junior researcher, e-mail: Tatyana_libra@mail.ru; Semkin Pavel Yu., junior researcher, e-mail: Pahno@, list.ru; Barabanshchikov Yury A., post-graduate student, e-mail: biw90@mail.ru; Zorin Stanislav A., post-graduate student,e-mail: stive01@mail.ru. 
wastes. According to Guseva (2000) Classifier of microbiological pollution, the Razdolnaya water is referred to «dirty» class in summer, to «polluted» class in spring and autumn, and to «clean» class in winter. The surface water of the Razdolnaya River does not meet hygienic standards for the sanitary-indicative microorganisms (CCB and TCB) because of its high fecal contamination. Besides, contamination of the Razdolnaya water by heavy metals is tested by microbial indication: notable contamination by lead and cadmium is revealed, the concentrations of zinc, nickel and copper exceed the background slightly, and the concentration of cobalt is insignificant.

Key words: Razdolnaya River, ecological-trophic groups, coliform bacteria, bacteria of sulfur cycle, nitrification, microbecenosis.

\section{Введение}

Река Раздольная - самая протяженная и экономически значимая водная артерия юга Приморья (Никаноров, Брызгало, 2011). Ее бассейн - один из самых крупных сельскохозяйственных районов края. Там же расположено около 70 промышленно-хозяйственных предприятий (угледобывающие, пищевой промышленности, машиностроения, по производству строительных материалов), хорошо развита инфраструктура, в том числе автомобильные и железнодорожные транспортные сети. Водные ресурсы бассейна очень важны для населения как источник бытового и питьевого водоснабжения, место отдыха. Кроме того, р. Раздольная имеет определенное рыбохозяйственное значение: здесь добываются рыбы (красноперка, пеленгас, корюшка и др.), японская корбикула Corbicula japonica и японский мохнаторукий краб Eriocheir japonica (Казанский, 1971; Явнов и др., 2001; Семенькова, 2007; Симакова, 2009; Большаков, 2014).

В то же время интенсивное освоение природных богатств южной части Приморского края способствует значительному загрязнению водных экосистем бассейна $\mathrm{p}$. Раздольной. Основные источники загрязнения - животноводческие и промышленнохозяйственные предприятия, места хранения органических и минеральных удобрений, сельскохозяйственные поля, коммунально-бытовые и промышленные сточные воды г. Уссурийск (Никулина, 2006). Вместе со сточными водами в реку могут попадать возбудители таких кишечных инфекций, как брюшной тиф, паратифы, дизентерия и др., способные сохраняться в воде длительное время и представляющие опасность для жителей регионов. В то же время микроорганизмы являются естественными обитателями пресных вод и играют важную роль в процессах их самоочищения, круговороте веществ, способствуя очищению вод от различных видов загрязнений (Sinsabaugh, Foreman, 2001; Branco et al., 2005; Hamonts et al., 2014). Поэтому исследование процессов, происходящих с участием микроорганизмов в реке, и микроорганизмов-индикаторов фекального загрязнения для оценки качества вод р. Раздольной представляется актуальным. Несмотря на многочисленные исследования биоты в водах реки (Казанский, 1971; Никулина, 2006; Семенькова, 2007; Силина, 2009; Колпаков, Милованкин, 2010; Большаков, 2014), изучение микроорганизмов в р. Раздольной до сих пор не проводилось.

В связи с этим целью работы было рассмотреть сезонное распределение численности различных эколого-трофических групп микроорганизмов в р. Раздольной и оценить качество вод реки по микробиологическим показателям.

\section{Материалы и методы}

Объектом исследования была р. Раздольная, расположенная на юге Приморского края. Площадь водосбора реки на территории России составляет 7300 км², с протяженностью на этом участке, равной 192 км. При среднемноголетнем расходе реки, равном $72 \mathrm{M}^{3} / \mathrm{c}$, соответствующий среднегодовой объем водного стока составляет 2,27 км $^{3}$ (Гомоюнов, 1927). Пробы воды отбирали в районе с. Раздольного (координаты

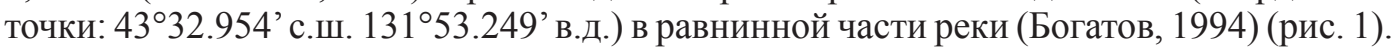

Все пробы воды отбирались на одной станции посезонно (июль, сентябрь, январь, апрель) в течение 2013-2014 гг. в трех повторностях.

Микробиологический анализ проводился в лаборатории гидрогеохимии и океанического литогенеза ДВГИ ДВО РАН. Пробы воды отбирались из поверхностного 
слоя стерильными пластиковыми шприцами объемом 20 мл и анализировались в день отбора. В водах р. Раздольной оценивали численность и характер сезонного распределения различных индикаторных групп микроорганизмов. Наиболее вероятное количество бактерий геохимических циклов углерода, азота, серы, железа и марганца оценивали методом предельных разведений с использованием элективных сред (Кузнецов, Дубинина, 1989). Для определения наиболее вероятного числа клеток микроорганизмов использовали таблицу Мак-Креди (Егоров, 1983). Численность колониеобразующих форм бактерий учитывали методом высева по Коху (Наливайко, 2006). Для определения количества микроорганизмов, синтезирующих экзогенные гидролазы липазу, амилазу, казеиназу, высев проводили на голодный агар с добавкой в качестве субстрата оливкового масла, твин-80, крахмала, молока (Кузнецов, Дубинина, 1989). Анализ численности колониеобразующих форм гетеротрофных микроорганизмов проводился на питательном бульоне с добавлением 1,5 \% агара. Количество металл-резистентных форм в сообществе гетеротрофных культивируемых микроорганизмов определялись на селективных средах, приготовленных на основе питательного агара с добавками солей металлов в концентрациях, ингибирующих рост чувствительных форм бактерий. В качестве добавок использовали хлориды металлов $\mathrm{Cd}, \mathrm{Zn}, \mathrm{Ni}, \mathrm{Cu}$, Со и нитрат $\mathrm{Pb}$ (Димитриева, Безвербная, 2002). Уровень фекального загрязнения оценивали на основе учета общих колиформных бактерий (ОКБ) и термотолерантных колиформных бактерий (ТКБ), культивируемых на селективной среде Эндо. Определяли каталазоположительные, оксидазоотрицательные грамотрицательные бактерии. Учет ОКБ и ТКБ производили согласно санитарным правилам (СанПиН 2.1.5.980-00).

Гидрохимический анализ проб проводился в лаборатории гидрохимии ТОИ ДВО РАН. Определялись следующие параметры: $\mathrm{O}_{2}$, биологическое потребление кислорода $\left.(\text { БПК })_{5}\right), \mathrm{pH}$, хлорофилл «а» (Хл), взвешенное вещество (BВ) и гумусовое вещество (ГВ). Одновременно производилось зондирование профилографом RBR XRX-620 c датчиками температуры, электропроводности, давления, флюоресценции хлорофилла, фотосинтетической активной радиации и мутности. Образцы воды в тот же день доставлялись в лабораторию, где проводился их анализ. Концентрацию $\mathrm{O}_{2}$ и БПК 5 определяли методом Винклера*. Точность определения \pm 0,05 мг/л, определяемые концентрации - выше 0,2-0,3 мг/л. Для измерения $\mathrm{pH}$ нами использовалась проточная ячейка безжидкостного соединения объемом $~ 80 \mathrm{~cm}^{3}$. Термостатирование проводили с помощью

* Методы гидрохимических исследований основных биогенных элементов : монография. М.: ВНИРО, 1988. 119 с. 
термостата фирмы VWR Scientific, модель 1146. ЭДС ячейки регистрировалась с точностью $0,1 \mathrm{mB}$ pH-метром, модель 920 фирмы «Orion». Значения $\mathrm{pH}$, полученные в шкале Питцера, затем пересчитывались в шкалу «общей концентрации водородных ионов» $\mathrm{pH}_{\mathrm{T}}$ О Ошибка измерений находилась в пределах $\pm 0,003$ ед. $\mathrm{pH}$ (Тищенко и др., 2002). При определении концентраций Хл пробы речной воды фильтровались на воронках с диаметром фильтров 35 мм и размером пор 0,4 мкм. Фильтрование производилось в лаборатории под давлением 1,3 м водного столба. Хлорофилл из фильтров экстрагировали 5 мл 90 \%-ного ацетона. Концентрацию Хл измеряли спектрофотометрическим методом (Кобленц-Мишке, 1983) на спектрофотометре Shimadzu модели UV-1650 РС. При измерениях записывался спектр поглощения экстракта в диапазоне длин волн 400-750 нм. Для расчетов использовали величину оптической плотности в максимуме при длине волны 664 нм. Ошибка метода около 10 \%. ГВ определяли спектрофотометрическим методом. В образцах проб измеряли оптическую плотность при длине волны 254 нм на спектрофотометре модели UV-1650 PC фирмы Shimadzu (Тищенко и др., 2006). Воспроизводимость данного метода оценивалась нами в 2 \%. Для определения количества ВВ использовали стекловолокнистые фильтры «Ватман» (диаметр фильтра 47 мм, размер пор 0,7 мкм), которые предварительно высушивали до постоянной массы в сушильном шкафу при $60{ }^{\circ} \mathrm{C}$. Фильтрование воды производили в лаборатории под давлением 1,3 м водного столба. После этого фильтры вновь сушили до постоянной массы в сушильном шкафу при $60^{\circ} \mathrm{C}$. По разнице массы фильтров до фильтрации и после рассчитывали концентрацию ВВ.

\section{Результаты и их обсуждение}

Химический состав речных вод очень чувствителен не только к антропогенному влиянию, но и к условиям окружающей среды: климату, рельефу, составу почвенного покрова и геологических пород на водосборе. Приморский край расположен в зоне гумидного климата, т.е. количество выпавших атмосферных осадков превалирует над испарением. Для такой климатической зональности характерна низкая минерализация речных вод (50-200 мг/л), основными компонентами которых будут ионы кальция, магния и гидрокарбоната. Согласно классификации О.А. Алекина, воды р. Раздольной относятся к группе гидрокарбонатного-кальциевого класса вод.

Характерная особенность гидрологического режима рек Приморского края - выраженная сезонная изменчивость стока*. Этот фактор во многом определяет химический состав речной воды (Алекин, 1970). В годовом ходе температуры воды отчетливо выделяется годовая гармоника, которая формируется под действием основных климатообразующих воздушных масс**. Сезонная изменчивость температуры речных вод наиболее очевидна и ожидаема. Ранее одним из авторов данной статьи (Михайлик и др., 2011) была исследована сезонная изменчивость концентраций биогенных веществ (нитратов, нитритов, аммония, фосфатов, силикатов), растворенного кислорода, растворенного органического вещества, хлорофилла, гумуса и взвешенного вещества на 8 станциях р. Раздольной. Результаты позволили установить основные источники загрязнения р. Раздольной в разные сезоны, а также объяснить особенности сезонной изменчивости химического состава речных вод. Результаты оценки гидрохимических параметров р. Раздольной на период отбора проб воды приведены в табл. 1. Тенденция изменчивости параметров в целом согласуется с полученными ранее нами и другими исследователями (Шулькин, 2009; Шулькин, Семыкина, 2012) результатами.

Результаты анализа микробиологического состава поверхностных вод p. Раздольной показали, что количество микроорганизмов сапрофитов-копиотрофов (СКТ) в воде варьировало в довольно широких пределах — от $2,5 \cdot 10^{3}$ до $4,4 \cdot 10^{5}$ кл./мл, в среднем указывая на высокий уровень органического загрязнения вод (табл. 2).

* Ресурсы поверхностных вод СССР. Основные гидрологические характеристики. Л.: Гидрометеоиздат, 1977. Т. 18, вып. 3. 245 с.

** Климат Владивостока. Л.: Гидрометеоиздат, 1983. 248 с. 
Таблица 1

Результаты оценки гидрохимических параметров р. Раздольной на период отбора проб воды

Table 1

Chemical parameters of the Razdolnaya River water for the sampling time

\begin{tabular}{|c|c|c|c|c|c|c|c|}
\hline Дата отбора & $\mathrm{T},{ }^{\circ} \mathrm{C}$ & $\mathrm{pH}$ & $\mathrm{O}_{2}, \mathrm{мг} / л$ & БПК, мг/л & Хл, мкг/л & ГВ, мгС/л & ВВ, мг/л \\
\hline 24.04 .2013 & 7,4 & 7,069 & 11,57 & 1,24 & 5,98 & 3,49 & 10,7 \\
\hline 04.07 .2013 & 20,2 & 6,917 & 7,54 & 1,19 & 7,67 & 6,71 & 154,5 \\
\hline 29.09 .2013 & 15,4 & 7,192 & 9,75 & 2,09 & 19,26 & 3,91 & 11,9 \\
\hline 21.01 .2014 & 0,1 & 6,602 & 7,34 & 2,65 & 2,98 & 1,87 & 3,0 \\
\hline
\end{tabular}

При этом наибольшая численность СКТ отмечалась в летний сезон, что совпадало с более высокой температурой воды в р. Раздольной в этот период. Согласно классификатору качества вод (Гусева и др., 2000) воды р. Раздольной по микробиологическим показателям (СКТ) отнесены к грязным в летний сезон, к загрязненным в весенний и осенний периоды и к чистым в зимний сезон. Численность олиготрофных сапрофитных бактерий в поверхностных водах р. Раздольной составляла в среднем $1,6 \cdot 10^{4}$ кл./мл и была на порядок ниже среднего количества СКТ (табл. 2). Так как олиготрофы приспособлены к существованию в эконишах с постоянно низкими потоками вещества и энергии, то постоянное поступление органических веществ со сточными водами в воды р. Раздольной могло лимитировать их рост. Значимым критерием для характеристики качества природных вод является индекс олиготрофности, представляющий отношение числа олиготрофных бактерий, использующих рассеянное органическое вещество, к числу копиотрофных бактерий, которым для жизнедеятельности необходимы концентрированные количества органических веществ. Индекс олиготрофности характеризует способность экологической системы к самоочищению. Если показатель индекса больше единицы, то это свидетельствует об активной минерализации органического вещества и способности данной экосистемы к самоочищению (Токаренко, 2006). Индекс олиготрофности в р. Раздольной был низок, его среднегодовые значения составили 0,2 , указывая на преобладание в поверхностных водах реки аллохтонного органического вещества над глубоко переработанным.

Таблица 2

Сезонная динамика численности (кл./мл) микроорганизмов различных функциональных групп в р. Раздольной (южное Приморье)

Table 2

Seasonal dynamics of microorganisms in the Razdolnaya water, by functional groups (cells $/ \mathrm{ml}$ )

\begin{tabular}{|c|c|c|c|c|}
\hline \multirow{2}{*}{$\begin{array}{c}\text { Функциональные группы } \\
\text { микроорганизмов }\end{array}$} & \multicolumn{4}{|c|}{ Сезон } \\
\hline & Лето & Осень & Зима & Весна \\
\hline \multicolumn{5}{|c|}{ Микроорганизмы геохимического цикла углерода } \\
\hline Сапрофиты-копиотрофы & $4,4 \cdot 10^{5}$ & $2,0 \cdot 10^{4}$ & $2,5 \cdot 10^{3}$ & $4,2 \cdot 10^{4}$ \\
\hline Сапрофиты-олиготрофы & $4,3 \cdot 10^{4}$ & $1,6 \cdot 10^{3}$ & $0,4 \cdot 10^{2}$ & $2,0 \cdot 10^{4}$ \\
\hline Индекс олиготрофности (олиг/копиотр) & 0,09 & 0,08 & 0,02 & 0,5 \\
\hline \multicolumn{5}{|c|}{ Микроорганизмы геохимического цикла азота } \\
\hline Азотфиксаторы & $8,0 \cdot 10^{2}$ & $2,4 \cdot 10^{2}$ & $0,3 \cdot 10^{2}$ & $4,5 \cdot 10^{3}$ \\
\hline Аммонификаторы & $3,5 \cdot 10^{2}$ & $1,7 \cdot 10^{2}$ & 0 & 0 \\
\hline Автотрофные нитрификаторы & $2,5 \cdot 10^{3}$ & $2,5 \cdot 10^{2}$ & $0,7 \cdot 10^{2}$ & $1,6 \cdot 10^{2}$ \\
\hline Гетеротрофные нитрификаторы & $1,7 \cdot 10^{5}$ & $4,9 \cdot 10^{4}$ & $2,9 \cdot 10^{3}$ & $1,4 \cdot 10^{4}$ \\
\hline Денитрификаторы & 0 & $0,9 \cdot 10^{2}$ & 0 & 0 \\
\hline \multicolumn{5}{|c|}{ Микроорганизмы геохимического цикла серы, железа и марганца } \\
\hline Тионовые бактерии & $0,4 \cdot 10^{2}$ & $0,9 \cdot 10^{1}$ & $0,9 \cdot 10^{1}$ & $2,5 \cdot 10^{3}$ \\
\hline Сульфатредукторы & 0 & $0,4 \cdot 10^{2}$ & 0 & 0 \\
\hline Железоокисляющие бактерии & $2,5 \cdot 10^{4}$ & $1,9 \cdot 10^{2}$ & $1,4 \cdot 10^{2}$ & $1,2 \cdot 10^{2}$ \\
\hline Железовосстанавливающие бактерии & $1,2 \cdot 10^{2}$ & 0 & $2,3 \cdot 10^{3}$ & 0 \\
\hline Марганецокисляющие бактерии & $1,4 \cdot 10^{1}$ & $6,8 \cdot 10^{3}$ & 0 & $1,5 \cdot 10^{3}$ \\
\hline Марганецвосстанавливающие бактерии & 0 & 0 & $3,2 \cdot 10^{3}$ & $0,4 \cdot 10^{2}$ \\
\hline
\end{tabular}


Изучение микроорганизмов круговорота азота в р. Раздольной показало, что основное участие в нем принимали бактерии аммонификаторы, автотрофные и гетеротрофные нитрификаторы. Численность аммонификаторов, осуществляющих разложение азотсодержащих органических веществ, была невысока и в среднем составляла $1,0 \cdot 10^{2}$ кл./мл (табл. 2). Процесс нитрификации в реке осуществляли автотрофные и гетеротрофные микроорганизмы, при этом численность последних была значительно выше во все сезоны исследования, что свидетельствует о существенном вкладе гетеротрофных бактерий в образование окисленных форм азота в результате разложения органических веществ в поверхностных водах р. Раздольной (табл. 2). Микроорганизмы, осуществляющие в анаэробных условиях процесс денитрификации, в поверхностных водах р. Раздольной $\left(0,2 \cdot 10^{2}\right.$ кл./мл) были развиты слабо, что, возможно, связано с подавлением их жизнедеятельности кислородом, присутствующим в поверхностных водах реки (см. табл. 1). В цикле серы преимущественное развитие получили хемолитоавтотрофные тионовые бактерии, при этом их численность в $\mathrm{p}$. Раздольной была невысока и варьировала от $0,9 \cdot 10^{1}$ до $2,5 \cdot 10^{3}$ кл./мл, а наиболее высокие ее значения были отмечены в весенний сезон (табл. 2). Сульфатредуцирующих бактерий, осуществляющих восстановление сульфатов до сероводорода, отмечено не было. Возможная причина этого - наличие высоких концентраций кислорода в водах реки, который, вероятно, подавлял жизнедеятельность анаэробных бактерий (см. табл. 1). Также в р. Раздольной были обнаружены гетеротрофные бактерии, окисляющие и восстанавливающие железо и марганец. Железоокисляющие бактерии были способны окислять двухвалентное железо до трехвалентного, при этом их рост сопровождался образованием на агаризованной среде ржавых колоний, часто с золотистым блеском. Численность активных железоокисляющих бактерий варьировала от $1,2 \cdot 10^{2}$ до 2,5 $10^{4}$ кл./мл, наибольшие их значения были отмечены в летний период (табл. 2). Количество гетеротрофных марганецокисляющих бактерий в р. Раздольной составляло в среднем $2,0 \cdot 10^{3}$ кл./мл, наиболее высокие значения наблюдали в осенне-весенние сезоны (табл. 2). Численность гетеротрофных бактерий, участвующих в процессах восстановления железа и марганца в р. Раздольной, в среднем была меньше количества бактерий, окисляющих железо и марганец.

Таким образом, можно сделать вывод, что органотрофные и литотрофные микроорганизмы были распространены в р. Раздольной и принимали участие в геохимических циклах углерода, серы, железа и марганца, участвуя таким образом в самоочищении вод р. Раздольной. Однако из-за постоянно поступающего потока сточных вод в реку бактерии не успевали до конца перерабатывать поступающее органическое вещество и ,таким образом, полного очищения вод реки не достигалось.

Чрезвычайно важную роль на начальных этапах расщепления органических субстратов играют микроорганизмы, выделяющие в среду гидролитические ферменты. Известно, что в зависимости от характера загрязнения преимущественное распространение получает микрофлора, обладающая той или иной специфической гидролитической активностью. Распределение этих микроорганизмов, их численность и активность могут отражать интенсивность процессов самоочищения вод, а также особенности загрязнения поверхностных вод*. В связи с тем, что р. Раздольная ежегодно подвергается хроническому воздействию легкоокисляемых органических веществ, поступающих со сточными водами, необходимо было оценить сезонную динамику численности гидролитически активной микрофлоры реки. Результаты исследования показали, что численность протеолитических микроорганизмов в водах р. Раздольной изменялась по сезонам неравномерно. Количество бактерий, проявляющих казеиназную активность, в р. Раздольной варьировало от 4,1 $\cdot 10^{2} \pm 12,3$ до $1,2 \cdot 10^{5} \pm 9605 \mathrm{KOЕ/мЛ,} \mathrm{составляя} \mathrm{в} \mathrm{среднем} 4,4 \cdot 10^{4}$ КОЕ/мл (рис. 2). При этом наибольшая численность микроорганизмов-протео-литиков

* Калитина Е.Г., Безвербная И.П., Бузолева Л.С. Динамика численности гидролитически-активной микрофлоры в условиях комплексного загрязнения бухты Золотой Рог // Электронный журнал «Исследовано в России». 2006. № 7. С. 56-66: http://zhurnal.ape.relarn.ru/ arcticles/2006/007.pdf. 
была отмечена в летний и осенний сезоны, что свидетельствует о наибольшем загрязнении поверхностных вод белоксодержащими органическими веществами в этот период, а также указывает на процессы расщепления белковых веществ, протекающие с участием микроорганизмов. Численность липолитических бактерий, являющихся индикаторами загрязнения веществами липидной природы, была ниже и изменялась от $1,1 \cdot 10^{2} \pm 9,5$ до $6,2 \cdot 10^{3} \pm 212 \mathrm{KOE} /$ мл, указывая на невысокий уровень загрязнения липидами (рис. 2). Наибольшие количества бактерий, выделяющих фермент липазу для расщепления жиров, наблюдались в летне-осенние сезоны, что может свидетельствовать об участии микроорганизмов в разложении липидов в р. Раздольной в эти периоды. Сезонная изменчивость численности микроорганизмов, синтезирующих фермент амилазу, была сходной с изменениями численности протеолитиков и липолитиков. При этом абсолютные значения численности были меньше, что свидетельствует о более низком уровне загрязнения реки углеводами (рис. 2).

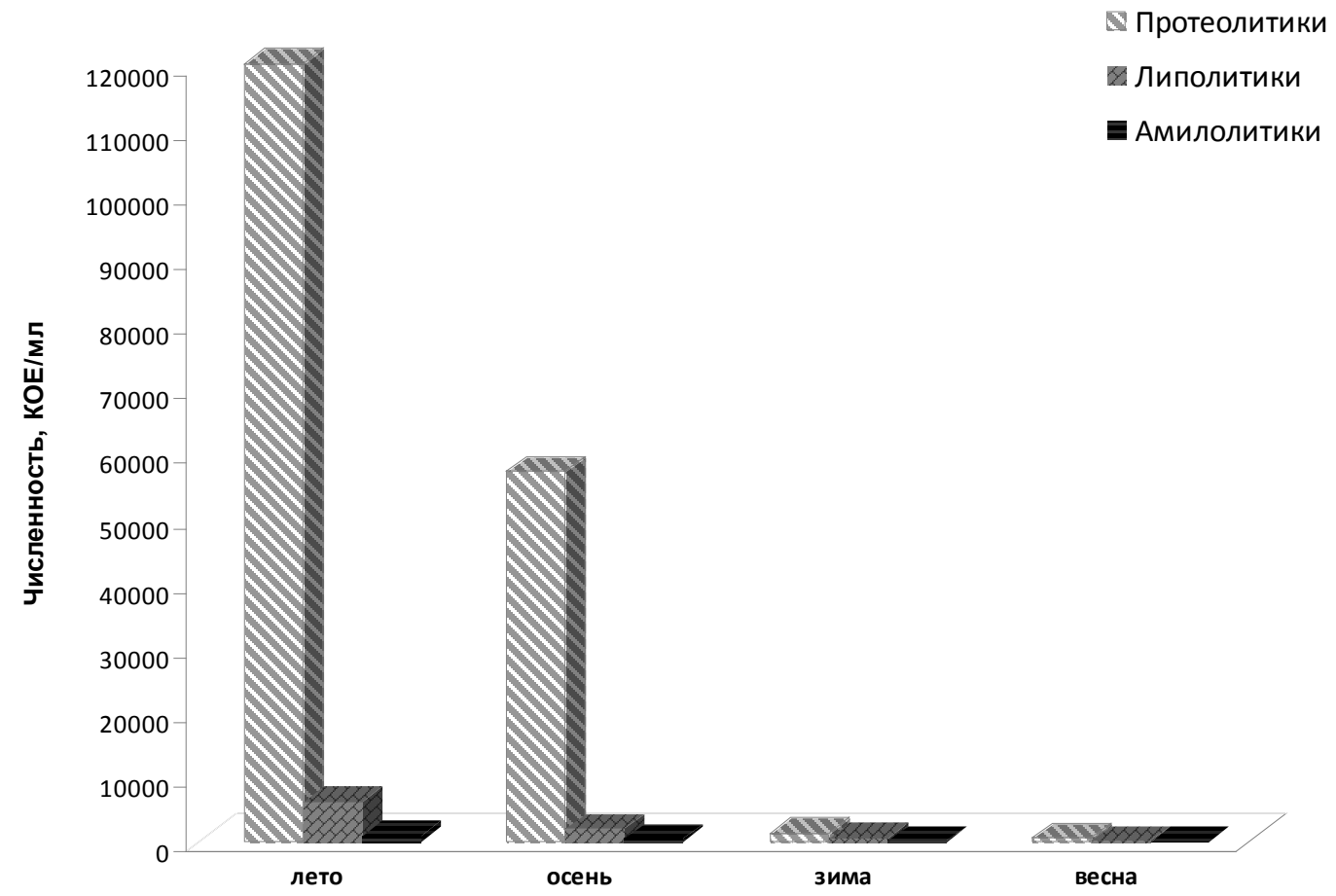

Рис. 2. Сезонная динамика численности микроорганизмов, обладающих экзогенной ферментативной активностью в водах р. Раздольной

Fig. 2. Seasonal dynamics of microorganisms with exogenous enzyme activity in the Razdolnaya water

Особую группу санитарно-показательных микроорганизмов, используемых для оценки качества среды, составляют колиформные бактерии, являющиеся индикаторами фекального загрязнения, а также свидетельствующие о возможной контаминации воды патогенными микроорганизмами кишечной группы.

Среди колиформных бактерий выделяли общие колиформные бактерии, грамотрицательные, не образующие спор палочки, не обладающие оксидазной активностью, ферментирующие лактозу или маннит с образованием альдегида, кислоты и газа при $37 \pm 0,5^{\circ} \mathrm{C}$ в течение 24 ч, а также термотолерантные колиформные бактерии, способные ферментировать лактозу до кислоты и газа при температуре $44{ }^{\circ} \mathrm{C}$ в течение 24 ч.

Результаты исследования санитарно-показательной микрофлоры в водах р. Раздольной выявили, что количество колиформных бактерий в поверхностных водах менялось по сезонам. Численность ОКБ в поверхностных водах реки была высока и изменялась от $3,6 \cdot 10^{2}$ до $4,8 \cdot 10^{3} \mathrm{KOE} /$ мл, при этом наибольшие количества бактерий были отмечены в летне-осенний сезон, что, вероятно, можно объяснить более высокими температурами в этот период, благоприятными для жизнедеятельности 
этих бактерий (рис. 3). В соответствии с гигиеническими нормами качества водных объектов численность ОКБ в водах хозяйственно-рекреационного водопользования не должна превышать $10 \mathrm{KOЕ/мл} \mathrm{(СанПиН} \mathrm{2.1.5.980-00).} \mathrm{В} \mathrm{поверхностных} \mathrm{водах} \mathrm{р.}$ Раздольной количество ОКБ превышало нормативные значения во все сезоны исследований, особенно осенью и летом (превышение соответственно в 430 и 480 раз), что свидетельствует о высоком фекальном загрязнении, а также о высокой контаминации вод реки условно-патогенной кишечной микрофлорой. Индикаторы свежего фекального загрязнения, ТКБ, были отмечены в р. Раздольной только в весенне-летний период, при этом их численность составляла 50-120 КОЕ/мл при допустимой норме $1 \mathrm{KOЕ/мл}$ (рис. 3). Наибольшее количество ТКБ в реке было отмечено в весенний сезон, при этом показатели превышали нормативные значения в 120 раз.

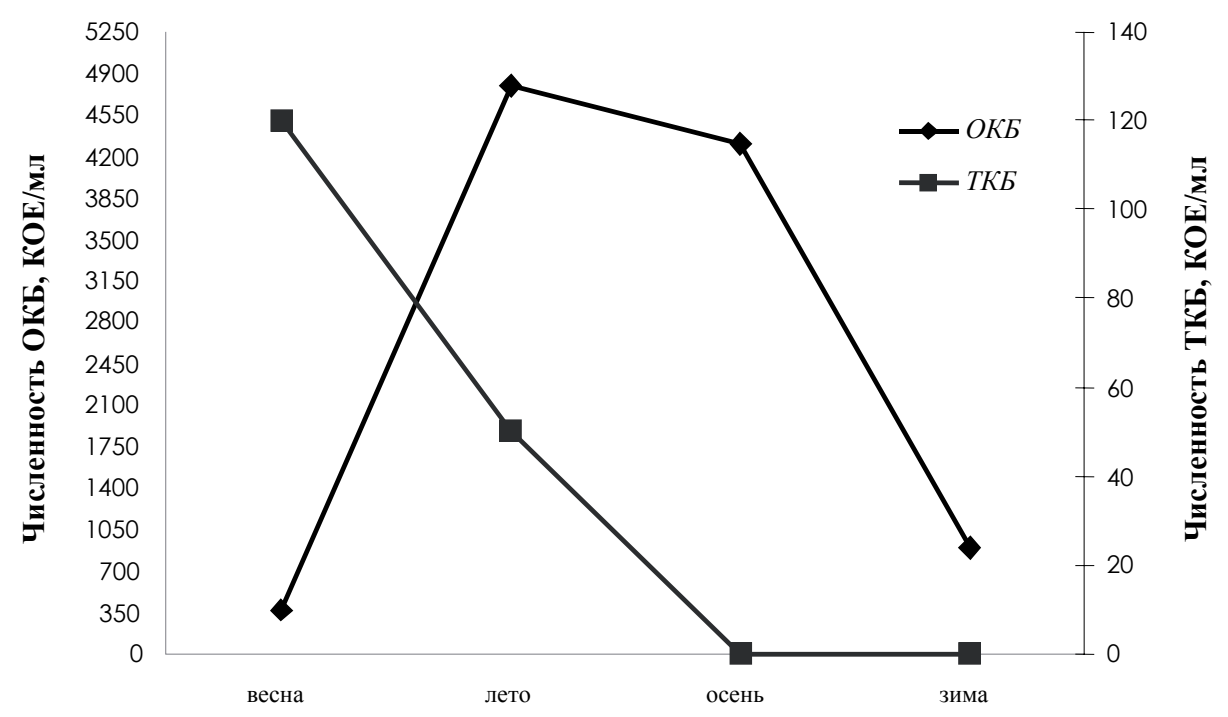

Рис. 3. Динамика численности общих колиформных бактерий (ОКБ) и термотолернатных колиформных бактерий (ТКБ) в поверхностных водах р. Раздольной (Норма ОКБ - 10 КОЕ/мЛ, ТКБ - 1 КОЕ/мЛ)

Fig. 3. Dynamics of abundance for common coliform bacteria (ОКБ) and thermo-tolerant coliform bacteria (ТКБ) in the surface water of the Razdolnaya River (the normal concentrations are 10 $\mathrm{CFU} / \mathrm{ml}$ and $1 \mathrm{CFU} / \mathrm{ml}$, accordingly)

Таким образом, поверхностные воды р. Раздольной не соответствовали гигиеническим нормативам по санитарно-показательным микроорганизмам (ОКБ, ТКБ), что свидетельствует об их высоком фекальном загрязнении.

Кроме высокого органического загрязнения р. Раздольная также подвержена загрязнению неорганической природы, наибольшую опасность представляют тяжелые металлы. Известно, что клетки разных микроорганизмов способны аккумулировать тяжелые металлы в высоких количествах, а также проявлять устойчивость фактически ко всем тяжелым металлам (Бузолева, Кривошеева, 2013). Установлено, что в условиях высокого загрязнения вод тяжелыми металлами формируются специфические микробоценозы, проявляющие резистентность к тяжелым металлам, и уровень устойчивости доминирующих форм бактерий к ним может характеризовать уровень загрязнения морских и пресных вод (Nies, 1999; Roane, Pepper, 2000; Димитриева и др., 2001; Журавель и др., 2004; Бузолева и др., 2006, 2008). Результаты исследования микроорганизмов, проявляющих устойчивость к тяжелым металлам, показали, что в микробной ассоциации реки присутствовали $\mathrm{Co}, \mathrm{Zn}, \mathrm{Cd}, \mathrm{Ni}, \mathrm{Pb}, \mathrm{Cu}$-толерантные бактерии, их численность варьировала от $1,9 \cdot 10^{3} \pm 220(\mathrm{Cd})$ до 5,7 $10^{4} \pm 1224 \mathrm{KOE} / \mathrm{Mл}(\mathrm{Pb})$, указывая на наличие в реке всех перечисленных элементов (табл. 3). В поверхностных водах р. Раздольной преобладали микроорганизмы, резистентные к свинцу, их доля в микробоценозе составляла $44 \%$, что указывает на высокое содержание в реке этого металла. Количество $\mathrm{Zn}, \mathrm{Cu}, \mathrm{Ni}$-устойчивых бактерий в гетеротрофном микробном 
сообществе реки было значительно ниже, но все же оставалось довольно высоким и составляло соответственно 3,8, 4,5, 6,0 \%, свидетельствуя о содержании повышенных концентраций этих элементов в воде (табл. 3). Так как $\mathrm{Cu}, \mathrm{Pb}$ и Ni являются маркерами техногенного влияния, то появление этих элементов в р. Раздольной, вероятно, связано со сбросами сточных вод промышленных предприятий. Наименьшую резистентность микроорганизмы проявляли к кобальту $(1,8 \%)$, при этом их средняя численность составляла $2,3 \cdot 10^{3} \mathrm{KOE/мл,} \mathrm{что,} \mathrm{возможно,} \mathrm{указывает} \mathrm{на} \mathrm{более} \mathrm{низкое} \mathrm{содержание}$ кобальта в воде р. Раздольной по сравнению с другими тяжелыми металлами ( $\mathrm{Zn}$, $\mathrm{Cd}, \mathrm{Ni}, \mathrm{Pb}, \mathrm{Cu}$ ). В соответствии с нормами (Димитриева и др., 2001) по содержанию устойчивых к тяжелым металлам форм бактерий (табл. 3), загрязнение поверхностных вод р. Раздольной классифицируется как ощутимое по содержанию кадмия и свинца, небольшое превышение фона наблюдается по количеству цинка, никеля и меди, а по наличию кобальта воды чистые.

Таблица 3

Численность гетеротрофных микроорганизмов, а также их металл-резистентных форм в поверхностных водах р. Раздольной

Table 3

Abundance of heterotrophic microorganisms and their metal-resistant forms in the surface waters of the Razdolnaya River

\begin{tabular}{|c|c|c|c|c|}
\hline $\begin{array}{c}\text { Группа } \\
\text { индикаторных } \\
\text { организмов }\end{array}$ & $\begin{array}{c}\text { Численность, КОЕ/мл } \\
\text { min-max } \\
\text { среднее значение }\end{array}$ & $\begin{array}{c}\text { Доля } \\
\text { устойчивых } \\
\text { форм, \% }\end{array}$ & $\begin{array}{c}\text { Норма (Димитриева } \\
\text { и др., 2001), \% }\end{array}$ & $\begin{array}{c}\text { Уровень } \\
\text { загрязнения }\end{array}$ \\
\hline $\begin{array}{c}\text { Гетеротрофные } \\
\text { микроорганизмы }\end{array}$ & $\frac{2,5 \cdot 10^{3}-4,4 \cdot 10^{5}}{1,2 \cdot 10^{5}}$ & - & - & - \\
\hline \multicolumn{5}{|c|}{ Бактерии, резистентные к тяжелым металлам } \\
\hline $\mathrm{Cd}$ & $\frac{6,8 \cdot 10^{2}-2,3 \cdot 10^{3}}{1,9 \cdot 10^{3}}$ & 1,5 & 0,01 & Ощутимое \\
\hline $\mathrm{Co}$ & $\frac{8,7 \cdot 10^{2}-2,7 \cdot 10^{3}}{2,3 \cdot 10^{3}}$ & 1,8 & 10,0 & Чисто \\
\hline $\mathrm{Zn}$ & $\frac{1,4 \cdot 10^{3}-5,0 \cdot 10^{3}}{4,9 \cdot 10^{3}}$ & 3,8 & 1,0 & $\begin{array}{c}\text { Небольшое } \\
\text { превышение фона }\end{array}$ \\
\hline $\mathrm{Ni}$ & $\frac{9,2 \cdot 10^{2}-8,1 \cdot 10^{3}}{7,8 \cdot 10^{3}}$ & 6,0 & 1,0 & $\begin{array}{c}\text { Небольшое } \\
\text { превышение фона }\end{array}$ \\
\hline $\mathrm{Pb}$ & $\frac{4,5 \cdot 10^{3}-6,3 \cdot 10^{4}}{5,7 \cdot 10^{4}}$ & 44,0 & 0,10 & \begin{tabular}{c} 
Ощутимое \\
\hline $\mathrm{Cu}$
\end{tabular} \\
\hline$\frac{2,1 \cdot 10^{2}-6,5 \cdot 10^{3}}{5,8 \cdot 10^{3}}$ & 4,5 & 0,10 & $\begin{array}{c}\text { Небольшое } \\
\text { превышение фона }\end{array}$ \\
\hline
\end{tabular}

Также изучали действие минимальной ингибирующей концентрации солей тяжелых металлов на размножение бактерий, выделенных из поверхностных вод р. Раздольной. Результаты показали, что ее действие на микроорганизмы по возрастанию можно расположить в следующий ряд: $\mathrm{Pb}^{2+}>\mathrm{Ni}^{2+}>\mathrm{Zn}^{2+}>\mathrm{Cu}^{2+}>\mathrm{Co}^{2+}>\mathrm{Cd}^{2+}$. Так, в большей степени для микроорганизмов были токсичны $\mathrm{Cd}^{2+}$ и $\mathrm{Co}^{2+}$, так как уже небольшие концентрации этих металлов (10-30 мг/л) угнетали размножение бактерий. Минимальная ингибирующая концентрация никеля и свинца (50-60 мг/л), по сравнению с другими элементами, была наиболее высока для микробов р. Раздольной, следовательно, никель и свинец в меньшей степени, по сравнению с другими тяжелыми металлами, тормозили рост исследуемых бактерий, что может быть связано с механизмами проникновения и воздействия тяжелых металлов на микробную клетку.

\section{Заключение}

Проведенные исследования показали, что поверхностные воды р. Раздольной подвержены высокому комплексному органическому, техногенному и микробиологическому загрязнению, которое обусловлено поступлением в реку аллохтонного вещества органической и неорганической природы. В поверхностных водах р. Раздольной выявлены 
органотрофные и литотрофные микроорганизмы, которые принимали участие в очищении вод реки, осуществляя геохимические циклы веществ, проявляя гидролитическую активность в отношении белков, жиров и углеводов. Однако из-за постоянно прибывающего потока сточных вод в реку бактерии не успевали перерабатывать поступающее органическое вещество и, таким образом, полного очищения вод реки не достигалось, что свидетельствует о неспособности данной экосистемы к полному самоочищению. Согласно классификатору качества вод (Гусева и др., 2000), воды р. Раздольной по микробиологическим показателям (СКТ) отнесены к грязным в летний сезон, к загрязненным в весенний и осенний периоды и к чистым в зимний сезон. Поверхностные воды р. Раздольной не соответствовали гигиеническим нормативам по санитарно-показательным микроорганизмам (ОКБ, ТКБ), что свидетельствует об их высоком фекальном загрязнении. Также по данным микробной индикации выявлено загрязнение поверхностных вод р. Раздольной тяжелыми металлами. В соответствии с нормами загрязнение водр. Раздольной классифицируется как ощутимое по содержанию кадмия и свинца, небольшое превышение фона наблюдается по количеству цинка, никеля и меди, а по наличию кобальта воды являются чистыми.

Работа выполнена при финансовой поддержке грантов РФФИ 11-05-00241-а и ДВО 14-III-B-07-009.

\section{Список литературы}

Алекин О.А. Основы гидрохимии : монография. — Л. : Гидрометеоиздат, 1970. — 444 с.

Богатов В.В. Экология речных сообществ российского Дальнего Востока : монография. Владивосток : Дальнаука, 1994. - 218 с.

Большаков С.Г. Биологическая характеристика эстуарных видов рыб реки Раздольная // Чтения памяти В.Я. Леванидова. - Владивосток : Дальнаука, 2014. - Вып. 6. - С. 104-109.

Бузолева Л.С., Безвербная И.П., Журавель Е.В., Калитина Е.Г. Микробиологический анализ загрязнения окраинных морей северо-западной части Тихого океана // Океанол. 2006. - T. 46, № 1. - С. 55-62

Бузолева Л.С., Калитина Е.Г., Безвербная И.П., Кривошеева А.М. Микробные сообщества поверхностных прибрежных вод бухты Золотой Рог в условиях высокого антропогенного загрязнения // Океанол. — 2008. - Т. 48, № 6. - С. 882-888.

Бузолева Л.С., Кривошеева А.М. Влияние тяжелых металлов на размножение патогенных бактерий // Успехи соврем. естествознания. - 2013. - № 7. - С. 30-33.

Гомоюнов К.А. Гидрологический очерк Амурского залива и реки Суйфуна // Производительные силы Дальнего Востока : тр. 1-й конф. - Владивосток, 1927. — Вып. 2. - С. 73-91.

Гусева Т.В., Молчанова Я.П., Заика Е.А. и др. Гидрохимические показатели состояния окружающей среды : справочные материалы. - М. : Эколайн, 2000. - 87 с.

Димитриева Г.Ю., Безвербная И.П. Микробная индикация - эффективный инструмент для мониторинга загрязнения прибрежных морских вод тяжелыми металлами // Океанол. 2002. 一 Т. 42, № 3. - С. 388-395.

Димитриева Г.Ю., Безвербная И.П., Христофорова Н.К. Микробная индикация возможный подход для мониторинга тяжелых металлов в дальневосточных морях // Изв. ТИНРО. - 2001. - Т. 128. - С. 719-736.

Егоров Н.В. Руководство к практическим занятиям по микробиологии. - М. : МГУ, 1983. - $220 \mathrm{c}$.

Журавель Е.В., Безвербная И.П., Бузолева Л.С. Микробная индикация загрязнения прибрежных вод Охотского моря и Авачинской бухты // Биол. моря. — 2004. - Т. 30, № 2. C. $138-142$.

Казанский Б.Н. Рыбные богатства внутренних водоемов Дальнего Востока и пути их воспроизводства // Уч. зап. ДВГУ. - 1971. - Т. 15, вып. 3. - С. 5-18.

Кобленц-Мишке О.И. Экстрактный и безэкстрактный методы определения фотосинтетических пигментов в пробе // Современные методы количественной оценки распределения морского планктона. - М. : Наука, 1983. - С. 114-125.

Колпаков Н.В., Милованкин П.Г. Распределение и сезонные изменения обилия рыб в эстуарии реки Раздольная (залив Петра Великого, Японское море) // Вопр. ихтиол. — 2010. Т. 50, № 4. - С. 155-166.

Кузнецов С. И., Дубинина Г.А. Методы изучения водных микроорганизмов : монография. - М. : Наука, 1989. — 288 с. 
Михайлик Т.А., Тищенко П.Я., Колтунов А.М. и др. Влияние реки Раздольной на экологическое состояние вод Амурского залива (Японское море) // Вод. ресурсы. - 2011. - Т. 38, № 4. - С. 474-484.

Наливайко Н.Г. Микробиология воды : учеб. пособие. — Томск : Изд-во Томск. политехн. ун-та, 2006. - 139 с.

Никаноров А.М., Брызгало В.А. Реки России. Ч. 4: Реки Дальнего Востока (гидрохимия и гидроэкология) : монография. — Ростов н/Д : НОК, 2011. - 324 с.

Никулина Т.В. Оценка экологического состояния р. Раздольная по составу индикаторных видов водорослей // Вестн. ДВО РАН. - 2006. — № 6. - С. 71-78.

Семенькова Е.Г. Биология и перспективы промысла японского мохнаторукого краба Eriocheir japonica в водоемах Приморья : дис. ... канд. биол. наук. - Владивосток, 2007. - 235 с.

Силина А.В. Мегабентос сублиторали приустьевой зоны реки Раздольной // Изв. ТИНPO. - 2009. - T. 157. - C. 95-106.

Симакова М.Г. Санитарно-гигиеническая оценка двустворчатого моллюска Corbicula japonica реки Раздольная Приморского края // Вестн. Алтайск. Гос. аграр. ун-та. — 2009. — № 6(56). - C. 42-44.

Тищенко П.Я., Вальманн К., Василевская Н.А. и др. Вклад органического вещества в щелочной резерв природных вод // Океанол. - 2006. - Т. 46, № 2. - С. 211-219.

Тищенко П.Я., Чичкин Р.В., Ильина Е.М. и др. Измерение рН в эстуариях с помощью ячейки безжидкостного соединения // Океанол. - 2002. - Т. 42, № 1. - С. 32-41.

Токаренко О.Г. Микробиологический состав минеральных вод Терсинского месторождения Кузбасса // Севергеоэкотех-2006 : мат-лы 7-й междунар. мол. науч. конф. - Ухта, 2006. - C. 384-387.

Шулькин В.М. Изменчивость химического состава речных вод Приморья как индикатор антропогенной нагрузки и ландшафтной структуры водосборов // Вестн. ДВО РАН. — 2009. № 4. - С. 103-114.

Шулькин В.М., Семыкина Г.И. Поступление загрязняющих веществ в залив Петра Великого и оценка их вклада в создание экологических проблем // Современное экологическое состояние залива Петра Великого Японского моря. — Владивосток : Изд. дом ДВФУ, 2012. C. $252-289$.

Явнов С.В., Лаженцева Л.Ю., Шульгин Ю.П. Санитарно-гигиеническая оценка моллюсков реки Раздольной Приморского края // Изв. ТИНРО. — 2001. — Т. 128. — С. 685-689.

Branco R., Chung A., Verissimo A. et al. Impact of chromium contaminated wastewaters on the microbial community of a river // FEMS microbiology ecology. - 2005. - Vol. 88, № 2. - P. 524-537.

Hamonts K., Ryngaert A., Smidt H. et al. Determinants of the microbial community structure of eutrophic, hyporheic river sediments polluted with chlorinated aliphatic hydrocarbons // FEMS microbiology ecology. - 2014. - Vol. 87, № 3. - P. 715-732.

Nies D.H. Microbial heavy-metal resistance // Appl. Microbial. Biotechnol. — 1999. — Vol. 51. - P. 730-750.

Roane T.M., Pepper I.L. Microbial responses to environmentally toxic cadmium // Microb. Ecol. - 2000. - Vol. 38. - P. 358-364.

Sinsabaugh R., Foreman L. Activity roles of bacterioplankton in a eutrophic river // Fresh water biology. - 2001. - Vol. 46. - P. 1239-1249.

Поступила в редакиџю 6.11.14 2. 